As an example, if we consider the case $f(s)=s^{-r}, p=1, q=\infty$, and use Laplace transforms, we obtain the integral representation for the Riemann zeta function

$$
\zeta(r)=\sum_{n=1}^{\infty} \frac{1}{n^{r}}=\frac{1}{\Gamma(r)} \int_{0}^{\infty} \frac{t^{r-1}}{\left(e^{t}-1\right)} d t \quad(R r>1)
$$

Alternatively, we may use our result to obtain a series from an integral. If we start with the integral form of the digamma function

$$
\psi(z)=-\gamma+\int_{0}^{\infty} \frac{\left(e^{-t}-e^{-z t}\right)}{\left(1-e^{-t}\right)} d t
$$

where the real part of $z$ is positive and $\gamma$ is Euler's constant, we obtain the series representation

$$
\psi(1+z)=-\gamma+\sum_{n=2}^{\infty}(-1)^{n} z^{n-1} \zeta(n) .
$$

References

1. G. G. Macfarlane, Phil. Mag. 40, 188-197 (1949).

2. J. G. Holbrook, Laplace transforms for electronic engineers, 274. Pergamon (1969).

NORMAN ANDERSON

Department of Mathematics, University of York

\title{
Obituary
}

\section{ROBERT LESLIE LINDSAY}

Bob, as he was known to his friends, was educated at the Preparatory School of St. Joseph's Convent, Reading, and in the Junior Department of Reading School until 1929 when he was admitted to Christ's Hospital, Horsham. It was his privilege and claim to fame at "C.H." that he served in the role of Drum Major on that historic and annual occasion when, on St. Matthew's Day, "the Lord Mayor most hospitably entertains the schools (boys and girls) at the Mansion House and distributes largesse. A token contingent of 300 boys and 25 girls are led by the school's famous band and marched along to the Mansion House". Bob went up to the University of Reading in 1939 to read classics. But the years of World War II intervened. He received his call-up papers in 1939 and was commissioned as a substantive captain in the Royal Artillery in which he served as a light antiaircraft gunner officer. He rose to the rank of Acting/Major and saw service with the 4th Indian Division of the 8th Army in El Alamein, Italy, Corsica, Salonica, Greece and France including a period from 1942 to 1945 without leave. He was demobbed in 1946 and returned to the University of Reading 
to complete his studies for the award in 1948 of the BA General Degree with Distinction in Latin and Mathematics. He followed this a year later with a good honours degree in Mathematics and in 1950 he obtained his Diploma in Education, again with Distinction.

In 1950 Bob was appointed as an Assistant Master to the staff of Reading School by the then headmaster, the late C. E. Kemp, also a mathematician and member of the Mathematical Association. He devoted much of his time to the activities of the Combined Cadet Force of which he was the commanding officer from 1955 to 1960 . It was his work with the C.C.F. at the school which introduced him to a life-time's commitment to computers. His "logical ironmongery" was the source of his motivation in most of his mathematical teaching. His interest in wireless and electronics led him to develop a set of pieces of home-made equipment incorporating transistors and logic gates. The younger boys were able to experience the joys of working with their own home-made computer whilst his mathematical scholars added, year by year, to the number of memory stores in the machine. One of his pupils contributed an article under the title "Antelope" which was published in the October 1968 issue of the Gazette. This article owed a very great deal to his pioneering work with logic and hardware at the school. His commitment to the C.C.F. was whole-hearted. He will perhaps be remembered best by some of his former pupils for his construction in the school ground, during the severe winter of 1962, of an "igloo" measuring 16 feet in base diameter and agout 8 feet high.

In his teaching he responded enthusiastically to the work of the School Mathematics Project and from the summer of 1963 he based his syllabus upon it and carried out trials of the project's draft texts. His own contribution in the sphere of electronics and his generally open and flexible approach found a ready application in the "modern" curriculum. Bob was joined by his family in his whole-hearted commitment to the life of Reading School in a wide-ranging way. His wife, Catherine, gave him loyal and unobtrusive support in all his endeavours, as matron-housekeeper-mother to their young charges. It was during their term of office at the school that they brought up their own young family. Their elder son, Richard, whom I remember meeting for the first time as a 3-year-old (he sat in the middle of a large circle of Reading University staff, student and ex-student guests of Professor E. H. Neville and his wife at one of their famous at-homes at the Copse, Sonning on Thames) was educated at Reading School. Their daughter, Anne, attended the local St. Joseph's Covent School where, as already mentioned, her Father had spent his early years and where I, too, had spent most of my schooldays. Peter, the youngest member of the family, was not old enough to attend Reading School with his brother before the family left Reading.

In 1965, Bob was appointed as Principal Lecturer in charge of mathematics at the then relatively new North Bucks College of Education at Bletchley under Mr. Sealey, a pioneer of "modern" primary mathematics. 
It was during his term of office at Bletchley that I was able to call on his expertise in computing. Whilst serving with the Nuffield Mathematics Teaching Project on my journeys to pilot schools in Norfolk, I was always assured of a very warm reception by Catherine-a very welcome change from hotel life-while Bob tested and validated with his students our own manually operated "table-top" computer. Constructed from the electronic scrapheap of 2-pole switches for the practical experience of very young children in the primary schools by one, David Simmons, this machine was termed the "bread-board" of the Nuffield Project! It was the first time, if not the only time, that I have been able to manipulate manualy a "computer"; to give the machine my own instructions which slowly at the rate of my own very slow computerised thought processes were translated into light bulb responses and followed by a "click" in the memory store to indicate that the instruction had in fact arrived in that store! Sad to relate, educational technology developed too swiftly for the work to bear fruition as a commercially produced plastic 'toy'. This however does not detract from my immense gratitude to Bob and his students for their enthusiastic response to my plea for help with my work for "Nuffield Maths".

At that time I was being urged to encourage schools to set up mathematics laboratories or mathematics teaching rooms. I invited Bob to help me. This he did with his customary enthusiasm. The result was his own edited Report of the Mathematical Association on Mathematics laboratories in schools: 1966, and the start of his own active and energetic role in the work of the Mathematical Association. Meanwhile he was promoted to VicePrincipal of North Bucks College of Education. But the college could not contain his energies. By this time he was looking for a more ubiquitous outlet for his work. My own work in Nuffield was drawing to a close. Although I had, unknowing to Bob, decided not to apply for a certain vacancy, it was indicative of his own generous nature and outgoing personality to help others that, as I later learned, Bob had left the way clear for me by not applying himself for that post. We became working partners as the first full-time lecturers appointed to the Shell Centre of Mathematical Education at Nottingham University. It was indeed a privilege to have worked with a person of Bob's stature and calibre. I should like to take this opportunity of letting his wife, Catherine, know-if she doesn't know already - that my work with Bob gave me three of the happiest years of my career. We looked upon ourselves as commercial travellers selling our modern mathematical wares. Our customers in the Midland and Eastern Counties of Nottinghamshire, Derbyshire and Lincolnshire, were often tough and critical of our enthusiasm. They often had too many other pressures in the form of school re-organisation and felt unable to commit themselves to new mathematical curricula that they didn't regard entirely as relevant. We had nothing to offer in the form of formal qualification at the end of a personal commitment to a 2-year or a 4-year course of in-service training at, usually, evening meetings in their own local school area. The 
most we could hope for was that a single thread might perhaps be woven into a fabric ultimately to be manufactured from the coordination and integration of the so-called traditional and modern topics of mathematics. It was only a very small beginning.

In his continuing work for the Centre Bob himself recorded that in his teaching he "experienced no such thing as a normal year". This was, in fact, the essence of his job. His lecture courses included: "Computer education" and "Mathematics for school leavers" to PGCE students; "History of mathematics of the Graeco-Roman era" to undergraduates in a 4-year first degree course in Mathematics and Education. He led conferences and seminars for specialist teachers of mathematics and crafts which were attended also by local education advisers, careers officers, employers and training managers. His contributions covered the different aspects of the mathematical requirements of the school leaver and remedial teaching. He extended his own teaching experience in schools on the workshop floor with remedial and "in-bin" pupils in the 14 to $16+$ age range-lecturers in the University Departments of Education are often accused of being out of touch with the classroom.

Whilst at the Shell Centre for Mathematical Education his publications included Basic skills in mathematics for engineering (1977), The mathematical needs of school leavers entering employment (1974 and 1975), and School mathematics in relation to craft and technician apprenticeships in the engineering industry (1976). He was an active member and contributor to the work of The Mathematics Teacher Education Programme (University of Leeds) and to The Schools Council Critical Review Project (the Mathematics Curriculum) which resulted in his own work Perspective drawing worksheets for the Shell Centre for Mathematical Education. His personal research interest was published in a paper The structure of dimensional analysis in electro-mechanical analogies in 1975. He attended the 4-yearly International Congress of Mathematical Education at Exeter in 1972 as Secretary of the geometry section, and at Berkeley in 1980 where he was invited to present two papers. He served on the Cockcroft Committee in the field of careers. This work led to joint publications by the Shell Centre for Mathematical Education and the Engineering Careers Information Service. It is understood from Professor Hugh Burkhardt, the Director of the Shell Centre, that the latest of these Numeracy in agriculture, was nearing completion at the time of his death and that it is to be published posthumously at the Shell Centre and in association with the Mathematical Association.

It is perhaps his investigations into the problems at the interface between school and apprenticeship that constitutes the most significant contribution in the field of mathematical education. These led to the running of tests in selected schools to assess the 'School leavers attainment profile of numerical skills'. He worked closely with A. Peter W. Collins, the then headmaster of Sutton Manor High School, who is "indebted to him for the wisdom, 
enthusiam and guidance he brought to this venture. His excellent work in research and dissemination was undoubtedly a significant reason for the interest shown in SLAPONS (a name which Bob suggested for the project) and it was a fitting reward that the Royal Society of Arts offered to administer the examination." Peter Collins was its Chief Examiner under Bob as its Moderator. The successful completion of the project was due in no small way to Bob's concern for detail and his objective reliable criticism. His high intellect quickly perceived the best way to write and evaluate the items in a logical manner. A colleague of Bob's calibre, on whom his team-mates in such a project could rely for advice was of inestimable value.

Bob's work with the Mathematical Association began with his appointment as Publications Secretary in 1966. He served as Hon. Treasurer and subsequently as Hon. Secretary. He has participated in the work of many of the major sub-committees of Teaching Committee and as a member of the Working Parties for "the defining of a mathematics core syllabus for schools" and "the conducting of a feasibility study for the Diploma for Teachers of Mathematics to Slow Learners". He was editor of Mathematics laboratories in schools (1966) and co-editor of Mathematics projects in British secondary schools (1966). He was an active Fellow of the Institute of Mathematics and its Applications and a member of the organising committee of its East Midlands Branch.

To those who were fortunate to get to know him well he became a special and inspiring friend. He had a natural concern for others and always appeared to have time to give to listening to, and entering into, their problems. He radiated assurance in times of crisis and one always felt happier when he was around. Outside of his professional interests his greatest joy was sailing. He would often describe his visits to the Broads and the boat which, I feel, must have given him a sense of complete and utter abandon during his two last holidays. It is an honour to have been asked to write an appreciation of a revered and respected friend of integrity and loyal devotion to duty. To Catherine and his family we offer our very sincere condolences.

Acknowledgment is made of the very great help received from his many friends in the preparation of this obituary, and particularly to: G. Baxendale-Baines (Nottingham University), A. Peter W. Collins (retired Headmaster of Sutton Manor School), John Hill (Schools and Industry Committee), Graham Merlane (HMI) and John A. Thurston (Branches Committee).

Bob leaves a large collection of books, lecture notes and transparencies and we are grateful to his widow and family who have agreed to donate these to the Mathematical Association. The University of Nottingham is instituting an annual Robert Lindsay Lecture. The first of these was held on the 21 st November 1985, given by Trevor Fletcher and entitled "Mathematics with your hands". 